\title{
Budgettering van ziekenhuizen : aspecten, trends en effecten
}

Citation for published version (APA):

Maarse, J. A. M. (1988). Budgettering van ziekenhuizen : aspecten, trends en effecten. Rijksuniversiteit Limburg. https://doi.org/10.26481/spe.19880422jm

Document status and date:

Published: 22/04/1988

DOI:

10.26481/spe.19880422jm

Document Version:

Publisher's PDF, also known as Version of record

\section{Please check the document version of this publication:}

- A submitted manuscript is the version of the article upon submission and before peer-review. There can be important differences between the submitted version and the official published version of record.

People interested in the research are advised to contact the author for the final version of the publication, or visit the DOI to the publisher's website.

- The final author version and the galley proof are versions of the publication after peer review.

- The final published version features the final layout of the paper including the volume, issue and page numbers.

Link to publication

\footnotetext{
General rights rights.

- You may freely distribute the URL identifying the publication in the public portal. please follow below link for the End User Agreement:

www.umlib.nl/taverne-license

Take down policy

If you believe that this document breaches copyright please contact us at:

repository@maastrichtuniversity.nl

providing details and we will investigate your claim.
}

Copyright and moral rights for the publications made accessible in the public portal are retained by the authors and/or other copyright owners and it is a condition of accessing publications that users recognise and abide by the legal requirements associated with these

- Users may download and print one copy of any publication from the public portal for the purpose of private study or research.

- You may not further distribute the material or use it for any profit-making activity or commercial gain

If the publication is distributed under the terms of Article $25 \mathrm{fa}$ of the Dutch Copyright Act, indicated by the "Taverne" license above, 


\title{
Budgettering van ziekenhuizen
}

\author{
aspecten, trends en effecten
}

\section{Rede}

In verkorte vorm uitgesproken bij de aanvaarding van het ambt van hoogleraar in de Beleidswetenschap an de Rijksuniversiteit Limburg op vrijdag 22 april 1988 door Dr. J.A.M. Maarse

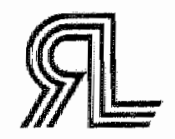

Rijksuniversiteit Limburg 
Voor José, Jet, Reineke en Annemarie 


\section{Inleiding}

Het is langzamerhand iedereen well duidelijk, dat de ujd wan forse expansic voor de gezondheidszorg achter ons ligt. De gezondheidszorg staat onder druk. Deze druk is de resultante van verscheidene factoren zoals bijvoorbeeld de gestage kritiek op de medicalisering van de zorg en de langzaam toenemende mondigheid van patiènten. Maar de meest belangrijke factor tot dusver betreft maar mijn mening het streven van de overheid naar beheersing van de gezondheidszorg. Het overheidsbeleid heef zich de afgelopen 10 à 15 jaar onmiskenbaar ontwikkeld in de richting van een beheersingsbeleid. ${ }^{1}$ Men kan geen nota of rapport meer openslaan, of er wordt wel ergens gerept over beheersing en dan in het bijzonder over kostenbeheersing.

Aan dit streven naar kostenbeheersing liggen een aantal overwegingen ten grondslag. Zo heeft in brede kring de mening post gevat, dat de gezondheidszorg op grote schaal door ondoelmatigheid wordt gekenmerkt. Het zou ondoeimaligg zijn deze te laten voortbestaan. Daarnaast word gewezen op de macro-cconomische effecten van de uitgaven voor gezondheidszorg. Een andere overweging is dat het principe van de gelijke financiële toegankelijkheid van de zorg - zo kenmorkend voor de verzorgingsstaat - op de tocht komt te staan, indien een effectieve kostcnbeheersing uitblijf.

Het zou een emstig misverstand zijn de kostenbeheersing in de gezondheidszorg ats een typisch Nederlands verschijnsel te beschouwen. Niets is minder waar. In het overgrote deel wan de geindustrialiseerde wereld staat kostenbeheersing hoog op de politicke agenda genoteerd. ${ }^{2} \mathrm{Zij}$ vormt kemnelijk een onvermijdelijke reactie op de enorme expansic die de gezondheidszorg na de Tweede Wereldoorlog heeft door gemaakt. In een recent rapport wan de OECD is bijwoorbeeld becijerd, dat in de OECD-landen in 1960 gemiddeld 4,2 procent van het brutonationaal inkomen aan de gezondheidszorg werd besteed. In 1984 bleek dit percentage tot 7,5 procent opgelopen. Volgens de OECD -becijferingen kwam Nederland in 1960 uit op 3,9 procent; voor 1984 bedroeg dit percentage 8,6 procent. ${ }^{3}$

De pogingen tot beheersing van de gezondheidszorg zijn gepaard gegaan met belangrijke wijzigingen in de positie van de overheid ten opzichte van de gezondheidszorg. Men spreckt in dit verband wel over de politisering van de

1 C.A. Grünwald, Beheersing van de gezondheidszorg, Utrech, 1987.

2 B. Abel-Smith, Cost containment in health care, Londen 1984; A. Maynurd, The regulation of public and private health care markets, in: $\mathbb{A}$. Maynard \& $\mathrm{G}$. McLachlan (eds), The public/private mix for health the relevance and effects of change, Londen, 1982, pp. $471-510$.

3 OECD Financing and delivering health care: a comparative analysis of OECD. countries, Parijs, 1987. 
gezondheidszorg. ${ }^{4}$ De term politisering brengt daarbij tot witdrukking, dat de overheid de besturing van de gezondheidszorg nadrukkelijk tot haar taak is gaan rekenen. In hoeverre het pleidooi van de Commissie-Dekker. ${ }^{5}$ voor een meer marktgerichte besturing van de gezondheidszorg hierin verandering zall brengen, moet overigens worden afgewacht. Het lijkt mij aan de vroege kant om nu al van een bestuurlijke trendbreuk te spreken. ${ }^{6}$

Met het oog op de beheersing wan de gezondheidszorg zijn met name vanaf 1975 een groot aantal beleidsinstrumenten ingezet. ${ }^{7}$ Die instrumenten betroffen onder meer het stelsel van ziektekostenverzekeringen en het alanbod van voorzieningen. Daamaast zijn er ook grote veranderingen in de wijze van bekostiging van de instellingen doorgevoerd. Het lijdt geen twijfel dat in dit verband de introductie van de budgettering van de intramurale gezondheidszorg wanaf 1983 de meest radicale beleidsmaatregel vormt. Volgens sommige waamemers ${ }^{8}$ bracht zij zelfs een ware aardverschuiving in de intramurale gezondheidszorg teweeg. Maar omdat deze "stille revolutic ${ }^{*}$ zonder directe consequenties voor de inkomensverdeling blijft, krijgt zij veel minder publicke belangstelling dan bijvoorbeeld de invoering van de basiswerzekering a la de Commissie-Dekker.

Heden wil ik in het bijzonder ingaan op enkele aspecten van deze budgettering. Daarbij zal ik mijn betoog om het terrein enigszins af te bakenen in het bijzonder toespitsen op de budgettering van de algemene ziekenhuizen.

De budgettering valt te beschouwen als een beleidsinstrument waarmee de overheid het gedrag van complexe organisaties in een bepaalde richting tracht te sturen." Daarmee is de bestudering van de budgettering ook vanuit beleidswetenschappelijk oogpunt een actueel thema. In de beleidswetenschap kan immers een groeiende belangstelling voor de instrumenten van het overheidsbeleid en in het bijzonder voor de ontwikkeling van een zogeheten instrumentenleer worden gesignaleerd. ${ }^{10}$

J.M. Boot \& M.H.J.M. Knapen, De Nederlandse gezondheidszorg, Utrecht, 1983, hoofdstuk 11.

5 Commissie-Dekker, Bereidheid tot verandering, Den Haag, 1987.

6 Zie bijvoorbecld J.A.M. Maarse, Het rapport-Dekker over de gezondheidszorg: vraagtekens bij de veronderstelde effecten, in: Beleidswetenschap, jrg 1, nr. 3, pp. $272-293$.

7 Zie Grinwald (1987) voor een overzicht wan de vele bezuinigingsmaatregelen.

8 A.P.W.P. van Montfort, Budgettering in de Nederlandse gezondheidszorg: stand van zaken, in: Acta Hospitalia, 1985/3, pp. 17-29.

9 Zie bijvoorbeeld L.J. van Gemerden et $\mathrm{al}_{*}$ Budgetfinanciering: een beleidsverkenning, Groningen, 1987.

10 J.Th.A. Bressers en J.P. Klok, Een voorlopige instrumententheorie van het milieubeleid, Enschede, 1986; in verkorte vorm: Grondslagen voor een instrumententheorie, in: Beleidswetenschap, no. 1, 1987, pp. 77-97; A.B. Ringeling, De instrumenten van beleid, Krimpen aan den IIssel, 1983. 
In mijn betoog zullen een aantal wragen centraal staan. Om te beginnen natuurlijk vragen als: wat is budgettering en wat. wordt ermee beoogd? welke veronderstellingen liggen eraan ten grondslag? Op welke wijze komt de budgetbepaling tot stand? Veronderstelt de budgettering een beheersmodel met daarin een sterke sturende rol voor de overheid? Of past zij ook goed bij cen meer marktgerichte besturing van de gezondheidszorg die thans zo in de politieke belangstelling staat?

Voorts zal ik ook enkelle effecten van de budgettering ter sprake brengen. Hicrbij beperk ik mij niet tot alleen de effecten op de kostenbeheersing. Daamaast zullen ook een aantal gevolgen voor de zorgverlening aan de orde komen. Voorts kan de budgettering worden beschouwd als cen belangrijke verandering in de omgeving van de ziekenhuizen waarop zij in hun beleidsvoering en met hun organisatic op adequate wijze zullen moeten inspelen. De door de budgettering teweeg gebrachite veranderingen in de beleidsvoering en organisatie van de ziekenhuizen vormen vanuit beleidswetenschappelijk oogpunt een derde belangwekkende categorie van effecten. 


\section{Budgettering en kostenbeheersing}

De invoering van de budgettering vanaf 1983 vormt voorlopig de laatste fase in een lang ontwikkelingsproces ten aanzien van de belkostiging van de ziekenhuizen. Het moderne ziekenhuis is woortgekomen uit het vroegere wooral door zusters gerunde gasthuis dat voorzag in verpleging en verzorging van met name minder draagkrachtige zieken. ${ }^{11} \mathrm{De}$ financiele positie van deze gasthuizen was doorgaans weinig rooskleurig. $\mathrm{Zij}$ waren voor hun inkomsten afhankelijk van onder meer legaten, giften en schenkingen van particulieren en liefdadigheidsinstellingen, van de ziekenbus en gemeentelijke armenbesturen. ${ }^{12}$ Daarnaast werden ook verpleeggelden gevraagd die door de zieken bij gebrek aan een deugdelijke ziektekostenverzekering zelf moesten worden opgebracht. Dat leverde soms grote problemen op. Zo zag het bestuur van het Wilhelminaziekenhuis te Assen zich ten tijde van de economische crisis op het eind van de jaren twintig genoodzaakt om de verplectgrijs van cến gulden tot vijftig cent te reduceren omdat een hogere prijs niet meer op te brengen viel. ${ }^{13}$

Met de invoering en ontwikkeling vam het stelsel wan ziektekostenverzekeringen verbeterde niet alleen de positie wan de zieken, maar ook de financiële positie van de ziekenhuizen. De ziektekostenverzekeringen boden de ziekenhuizen een veel steviger financieel fundament. Onder het regiem van de outputfinanciering - ook wel aangeduid als productiefinanciering - braken zelfs gouden tijden aan. Elke productie betaalde zichzelf, want een hogere productie had automatisch een stijging van de inkomsten voor het ziekenhuis tot gevolg. Als de bedbezetting maar op peil bleef, waren er nauwelijks financiele problemen. ${ }^{14}$

Met het oog op de kostenbeheersing was deze productiefinanciering uiteraard weinig aantrekkelijk. ${ }^{15}$ Het ziekenhuis had immers weinig belang bij kostentbeheersing en het zogeheten opbrengstgerichte denken tierde dan ook welig.

11 Zie bijwoorbeeld A.P.W.P van Montfort en J.H. Schaaf, Budgettering en management in ziekenhuizen, in: J.H. Peters, W.K. de Bruyn, G.J.M. de Cock en C.H.M. Kleemans (red.) "Management in de gczondheidszorg. Ulrecht /Antwerpen; I.M. Mur-Veeman, Ziekenhuisbeleid, Oss, 1982.

12 Zie bijwoorbeeld Een eeuw armen-en ziekenzorg in Venlo (verschenen ter gelegenheid van het 100 -jarig bestaan van het St. Joseph-ziekenhuis in Venlo).

13 Waar men den kranke, zoo ' $\mathrm{k} k \mathrm{kan}$, geneest... De 75-jarige geschiedenis van het Wilhelminaziekenliuis in Assen. Jubileumboek geschreven door Bertus Boivin en Chris van der Veen.

14 Zie bijwoorbeeld F.J.M. Werner, Inleiding Congres Gezondheid en Financiën, Rotterdam, 1985; L.M.J. Groot, Ziekenhuis en budget in een stagnerende economie, in: G. Schrijvers (red), Ziekenhuis en budget: Nederland, Amerika, Engeland en Zweden, Lochem, 1982.

15 Zie bijwoorbeeld A.P.W.P van Montfort \& J.H. Schaaf; P.L. Joskow, Controlling hospital costs, Cambridge (Mass), 1984. 
Toen met name vanal de tweede helft wan de jaren zeventig de bezuinigingen een steeds hogere prioriteit in het regeringsbeleid kregen, namen ook de pogingen tot kostenbeheersing in de gezondheidszorg toe. Daarbij werden ten aanzien van de ziekenhuizen aanvankelijk vooral twee wegen bewandeld. In de cerste plaats werd via de Wet Ziekenhuistarieven en later de Wet Tarieven Gezondheidszorg gekozen voor een restrictieve tariefstelling en een bijbehorende stringente kostenbeoordeling. Men zou hier dus kunnen spreken van kostenbeheersing door middel van centralisatie. ${ }^{16}$ De tweede weg betrof een versterkte regulering van het aanbod van voorzieningen. De wijziging respectievelijk uitbreiding van de planningswetgeving, de introductie van het bouwplafond en het beddenreductiebeleid zijn hiervan typerende voorbeelden.

Beide strategieën leverden echter betrekkelijk weinig resultaat op. Daarvoor zijn tal van oorzaken aan te geven. Zo verliepen de planning en vooral de arslanking van het aanbod van voorzieningen uitermate traag. ${ }^{17}$ Men denke in dit verband slechts aan de tragische lotgevallen van de beddenreductie en de Wet Voorzieningen Gezondheidszorg. Daamaast liet ook de effectiviteit van de aangescherpte regelgeving en controle te wensen over. ${ }^{18}$

In 1983 werd het roer omgegooid. In navolging van andere landen zoals Canada, Engeland en $\mathrm{Z}$ weden werd de weg van de budgettering ingeslagen. ${ }^{19}$ Deze budgettering betekende een drastische verandering in de wijze van bekostiging van de ziekenhuizen. Deze kregen nu voor een bepaald jaar een gegeven budget toegewezen (de zogeheten aanvaardbare kosten) waaruit de totale productie c.q. dienst verlening moest worden bekostigd. Een hogere productie respectievelijk dienstverlening leidde dus niet meer tot additionele inkomsten. Hiermee kwam een einde aan de productiefinanciering. 20

Uit het voorgaande komt zonneklaar naar voren, dat de budgettering alles te maken heeft met het streven naar kostenbeheersing in de gezondheidszorg. Over deze doelstelling wordt ook niet geheimzinnig gedaan. 'De invoering van het budgetteringssysteem, aldus de Nota Bouwbeleid, Beddenreductie en Budgettering, 'dient

16. J.A.M. Marse, Bezuinigingen en decentralusatie, Den Hag. 1986.

17 Vergelijk H.J.E. Krol en J. Passchier, Evaluatic planproces Wet Ziekenluis. woorzieningen, Utrecht, 1986 (NZI publicatie).

18. In de literatuur zijn hiervoor utvoerige verklaringen geboden. Zie bijvoorbeeld Joskow (1984); zie voorts $\mathbf{S}$. Eichhorn, System der Krankenhauffinanzierung in der Bundesrepublik Deutschland, in: F. Beske et al, in het bijzonder pp. 180182.

19 Zie W.A. Glaser, Paying the hospital: the organization, dyramics, and effects of differing financial arrangements, San, Francisco/Londen, 1987, in thet bijzonder hoofdstuk 8.

20 L.M.J. Groot, Ziekenhuiseconomic, Leuven, 1984. 
gezien te worden als een belangrijk middel om tot een daadwerkelijke beheersing van de kosten in de intramurale gezondheidszorg te geraken'.21 Daarnaast moet de budgettering ook bijdragen tot verruiming van de beleidsvrijheid van de ziekenhuizen.

Alvorens nader in te gaan op een aantal veronderstellingen die aan de budgettering ten grondslag liggen, wil ik eerst nog een hardnekkig misverstand uit de weg ruimen. Dit misverstand komt er kort gezegd op neer, dat de budgettering wordt verward met de bezuinigingen in de gezondheidszorg. Dat dit misverstand bestaat is niet zo verwonderlijk. De budgettering vergemakkelijkt het bezuinigingsproces en is dan ook meermalen gebruikt voor bezuinigingen op de intramurale gezondheidszorg. Daarmee is zij evenwel nog niet identiek aan bezuinigingen.

Ter werduidelijking van het verschil tussen budgetteren en bezuinigen is het nuttig om de situatie in Engeland met die in Zweden te vergelijken, beide landen waar de budgettering al weel langer bestaat. In Engeland wordt de gezondheidszorg al jaren achtereen afgeknepen, in Zweden is dat veel minder het geval. De oorzaak daarvan moet vooral in de politieke prioriteitstelling worden gezocht. Wat er aan geld in de gezondheidszorg omgaat, is onder het regime van de budgettering vooral een kwestie van politieke afweging. Een belangrijk punt betreft daarbij overigens wat tegen wat moet worden afgewogen. Het bijzondere van de Z weedse situatie zou wel eens kunnen zijn, dat de gezondheidszorg het vanwege de sterk regionale organisatie - ook ten aanzien van de financiering - niet tegen gevestigde nationale prioriteiten zoals bijvoorbeeld defensie behoeft op te nemen.

21 Nota Bouwbeleid, beddenreductie en budgettering, Den Haag, 1984, p. 20. Zie ook kamerstuk 17.600, hoofdstuk XVI, nr. 110, zitting 1982-1983. 


\section{Veronderstellingen}

In het moderne beleidswetenschappelijk onderzoek wordt niet volstaan met het opsporen wan de doeleinden en middelen van een beleid. Daarnaast krijgen ook de veronderstellingen die aan de gekozen doel-middel structuur ten grondslag liggen ruime aandach. Dit geheel van veronderstellingen wordt wel aangeduid met het begrip beleidstheorie. ${ }^{22}$ Een analyse van een beleidstheorie kan waardevolle inzichten in de werking en kansen van een belleid opleveren en tevens belangrijke aanknopingspunten bieden voor empirisch onderzoek en (kritische) evaluatiestudies.

Welke veronderstellingen gaan er achter de invoering van de budgettering schuil? Ik zal enkele van deze veronderstellingen kort doomemen. ${ }^{23}$ Een cerste weronderstelling is dat de budgettering de ziekenhuizen zal aanmoedigen tot een grotere doelmatigheid. De afschaffing van de productiefinanciering en de introductie van een uitgavenplafond nopen zowel in de klinische als in de meer bedrijfsmatige sfeer ${ }^{24}$ tot een betere interne afweging van kosten en opbrengsten. Daar komt vervolgens bij dat een ziekenhuis een eventueel positief saldo tussen uitgaven en budget zelf mag behouden. ${ }^{25}$ Omgekeerd draait het ziekenhuis zelf op voor eventuele tekorten. Kort samengevat, moet de budgettering dus fungeren als medicijn tegen verspilling en als zodanig bijdragen tot kostenbeheersing.

In deze eerste veronderstelling zit een tweede veronderstelling verborgen. Deze luidt dat er in de gezondheidszorg en in het bijzonder in de ziekenhuizen sprake is van een grote ondoelmatigheid. Deze ondoelmatigheid is het gevolg van het feit dat de productiefinanciering de noodzaak tot afweging van kosten en opbrengsten onderdrukt. Het spreekt voor zich dat het streven naar meer doelmatigheid door middel van de budgettering zonder deze veronderstelling weinig hout snijdt. Wat heeft het immers voor zin de doelmatigheid te bevorderen indien deze niet te wensen zou overlaten? Men kan z'n tijd en energie dan beter anders besteden.

De veronderstelling dat er in de gezondheidszorg sprake is van ondoelmatigheid opent de weg voor een derde belangrijke veronderstelling. Deze veronderstelling komt er kort gezegd op neer, dat de budgettering de kwaliteit van de zorgverlening

22 A. Hoogerwerf, Beleid berust op veronderstellingen: de beleidstheoriv, in: Acta Politica, jig. 19. 1984, pp. 493-527.

23 Vergelijk K.G. Bauer, Hospital rate-setting - This way to salwation?, in: M. Zubkoff, IE. Raskin en R. Hanft (eds), Hospital cost contaimment, New York, 1978.

24 Zie L. Wyszewianski, J.W. Thomas en B.A. Friedman, Casebased payment and the control of quality and efficiency in hospitals, in: Inquiry 24 , Spring 1987 . pp. 17-25.

25 De positieve saldi fungeren tevens als financiele kurk voor eventuele nadelige saldi in latere jaren. 
niet behoeft aan te tasten. Met minder middelen kan hetzelfde niveau worden bereikt. Misschien draagt de budgettering wel bij tot de kwaliteitsverbetering inzoverre er impulsen wan uitgaan om wormen van overmatige zorg terug te dringen.

Bevordering van doelmatig gedrag is gemakkelijker gezegd dan gedaan. Het gaat erom goed gedrag te belonen en slecht gedrag af te straffen. Maar wat is precies goed gedrag en wat slecht gedrag? Waar gaat bijvoorbeeld het streven naar doelmatigheid over in 'underserving', dat wil zeggen het verminderen van de dienstverlening om een bepaald budgetoverschot te realiseren? ${ }^{26}$ Hiermee kom ilk toe aan sen vierde veronderstelling, namelijk dat goed en slecht gedrag duidelijk van elkaar kunnen worden onderscheiden. Ik vermoed dat dit onderseheid in de praktijk nog wel eens problematisch zal blijken en in ieder geval de nodige wijsheid en takt van de betrokken partijen zal vergen. ${ }^{27}$

De budgettering veronderstelt in de vijfde plaats bestuurlijke betrouwbaarheid van de zijde van de budgetbepaler(s). Ziekenhuizen mogen niet worden gestraft voor het realiseren van bepaalde efficièntievoordelen. Straffen van doelmatig gedrag door middel van budgetkortingen duidt op bestuurlijke onbetrouwbaarheid die de bijl legt aan de wortels van de budgettering. Of die kortingen door de overheid dan wel door de verzekeraars worden opgelegd, maakt hierbij niet zoveel uit.

De invoering van de budgettering moet de doelmatigheid in de ziekenhuizen vergroten. Dat kan evenwel alleen indien de ziekenhuizen over voldoende keuzevrijheid beschikken. Doelmatigheid veronderstelt dus keuzevrijheid, anders wordt de beoogde interne afweging van de kosten en opbrengsten van gedragsalternatieven al bij voorbaat in de kiem gesmoord.

Met deze zesde veronderstelling kom ik toe aan een belangrijk aspect van de budgettering, namelijk dat de budgettering ook dient als middel tot verruiming van de beleidsvrijheid van de ziekenhuizen. De invoering van een ziekenhuisbudget maakt immers cen groot aantal tariefvoorschriften en andere richtlijnen overbodig. Vanuit de optiek van de ziekenhuizen vormt deze deregulering een aantrekkelijk perspectief. Het verstikkende oerwoud van richtlijnem liet immers weinig ruimte voor een meer zelfstandige beleidswoering en vergde valak het uiterste van de bestuurlijke en boekhoudkundige creativiteit van de directies om toch nog wat ruimte te scheppen. Als wij de voormalige staatssecretaris Van der Reijden mogen geloven, hebben de instellingen onder aanvoering van de Nationale Ziekenhuisraad zich mede vanwege dit perspectief achter de budgettering geschaard. ${ }^{28}$

26 Zie Schaaf en Van Montfort (1984), pp. $28-29$.

27 Glaser (1987) beschrijft in zijn studie een in Quebec ontwikkelde methode om te differentierren tussen het bereiken van doelmatigheidsvoordelen en thet realiseren van budgetoverschotten langs de weg van de "underserving'. Zie in het bijzonder pp. 188 .

J.P. van der Reijden, Onze kostelijke gezondheidszorg, Amsterdam, 1987. 
Een interessante vraag is naturlijk in hoeverre de budgettering een daadwerkelijke verruiming van de beleidsvrijheid van de ziekenhuizen heeft opgeleverd. Voorzover mij bekend, bestaat hiernaar tot dusver geen onderzoek. Mijn inschatting is evenwel dat men zich van deze verruiming geen overtrokken voorstelling moet maken. In dit verband valt bijvoorbeeld te wijzen op de vele kwaliteitseisen in de plannings- en verzekeringswetgeving die onverkort wan kracht zijn gebleven.

Aan de budgettering ligt tenslotte nog een zevende cruciale veronderstelling ten grondslag, namelijk dat ziekenhuisdirecties in staat zijn de beoogde verbetering van de doelmatigheid ook daadwerkelijk in praktijk te brengen. Zij dragen immers de uiteindelijke verantwoordelijkheid voor het financiele resultaat. Deze laatste veronderstelling speelt in de discussie over de budgettering een belangrijke rol. Daarbij wordt de discussie vooral toegespitst op het beperkte bereik van de budgettering. De verrichtingen (en overige praktijkkosten) van de vrijgevestigde specialisten vallen immers niet onder de budgettering. De budgettering woorziet dus niet in een beheersing van de medisch-specialistische zorg. Tegelijkerijd brengt deze zorg wel allerlei kosten mee die ten laste komen van het ziekenhuisbudget.

Het spreekt welhaast voor zich dat deze compromisachtige constructie zeer hoge eisen stelt aan de besturing van ziekenhuizen, vooral ook tegen de achtergrond van de budgetkortingen die de ziekenhuizen opgelegd hebben gekregen. In de visie van de Commissie-Dekker kan deze situatie dan ook niet blijven voortbestaan. De Commissie stelt als oplossing voor om de medisch-specialistische hulp onder het ziekenhuisbudget te brengen en tegelijkertijd door middel van een bonus/ malus regeling prikkels in de honorering van de specialisten in te bouwen. De Commissie acht uitvoering van dit voorstel een belangrijke voorwaarde voor het bevorderen van wat zij aanduidt als een geïntegreerde bedrijfsvoering. Een alternatieve mogelijkheid zou kunnen zijn de medisch-specialistische hulp niet onder het ziekenhuisbudget te brengen, maar meer over te schakelen op een systeem van tijdelijke contracten tussen instelling en specialist waarin de wederzijdse rechten en plichten zijn vastgelegd. ${ }^{29}$ Een dergelijke strategie laat de zelfstandigheid van de specialist in stand. Zij vergroot de flexibiliteit voor de ziekenhuisdirecties, maar dwingt hen tegelijkertijd tot explicitering van de doeleinden en belangen van de eigen organisatie. Tevens noopt zij de instellingen tot bezinning over de vraag hoe de faciljteiten die zij de specialist te bieden heeft kunnen worden uitgebreid. Tijdelijke contracten kunnen naar mijn mening dus bijdragen tot een goede alstemming van de belangen en de doelstellingen tussen de contracterende partijen. De huidige levenslange contracten lijken mij in ieder geval rijp voor krilische overweging.

Commissie-Dekker (1987), p. 74. De idee wan tijdelijke contracten vindt men onder meer uitgewerkt bij A. Sheldon, Managing Doctors, Homewood (Illinois), 1986 
Tot zover een bespreking van enkele veronderstellingen die aan de budgetlering ten grondslag liggen. Ik heb niet de pretentie dat het geboden overzicht uitputtend is. Maar voor mijn betoog is dat ook niet noodzakelijk. Ik hoop voldoende te hebben aangetoond, dat het opsporen en analyseren van de veronderstellingen achter een beleidsinstrument een goed inzicht kunnen bieden in de werking en kansen wan dat instrument. Tevens verschaft een dergelijke analyse waardevolle aanknopingspunten voor empirisch onderzoek en (kritische) evaluaties, bijvoorbeeld betreffende de wraag naar de empirische validiteit wan de beleidstheorie. 


\section{Budgetbepaling}

Wie kiest voor budgettering, ziet zich direct voor lastige vragen geplaatst: hoe moet het totale budget worden verdeeld? hoe moet de omvang van een ziekenhuisbudget worden bepaald? wat is een doelmatige en rechtvaardige budgetformule? Met dit vraagstuk van de externe budgettering lopen wij niet alleen op tegen een technisch probleem, maar ook tegen een probleem dat bestuurlijk erg gevoelig kan liggen. ${ }^{30}$ Directies van ziekenhuizen zullen immers vooral geinteresseerd zijn in de financiele implicaties van de budgettering voor hun instelling. Dat kan een rolconflict opleveren zoals bijvoorbeeld bij een ziekenhuiseconoom die als econoom best waardering kon opbrengen voor de opzet van de functionele budgettering, maar er als economisch directeur grote bezwaren tegen koesterde omdat zijn ziekenhuis bij de invoering ervan tot de verliezers behoorde.

De budgetbepaling kan op uiteenlopende manieren worden opgezet. Het Nederlandse systeem van budgetteren wordt in de literatuur wel aangeduid als 'global budgeting'. ${ }^{31}$ Per ziekenhuis wordt een budget bepaald waaruit het de totale productie c.q. dienstverlening gedurende een bepaalde periode moet bekostigen. Deze opzet wijkt sterk af van het zogeheten Prospective Payment System dat in de Verenigde Staten vanaf 1982 in het kader van Medicare wordt beproefd. Bij dit laatste systeem wordt niet zoals in Nederland de totale productie in een bepaald jaar gebudgetteerd, maar de behandeling van een bepaalde diagnosegroep. Vandaar dat men het Amerikaanse systeem ook wel aanduidt als case-based payment. ${ }^{32}$

Beziet men de opzet van de budgettering in Nederland, dan springen er mijns inziens een aantal ontwikkelingen uit. Om te beginnen is er een duidelijke koppeling tussen het plannings- en het budgetteringscircuit tot stand gebracht. Een deel van het ziekenhuisbudget wordt namelijk bepaald door de erkenningen waarover dat ziekenhuis beschikt. Tegen deze achtergrond moet men mede de commotie

30 Dit probleem is overigens zeker niet specifiek voor de gezondheidszorg. Ook in andere sectoren van het overheidsbeleid is de vaststelling wan de budgetformules met veel politieke strijd gepaard gegaan. Voorbeelden zijn de stadsvernieuwing en de bejaardenoorden.

31 Zie bijroorbeeld W.A. Glaser (1987); F. Beske, L. Delesie, F. Rutten en H. Zollner, Hospital financing systems, Kiel, 1987; G. Neubauer, Bausteine eines rationalen Krankenthausvergütungssystems, paper voor conferentie over Alternatieve Entgeltwerfahren in der Krankenhausversorgung, Stuttgart, 1987.

32 Zie hierover bijwoorbeeld J.K. Iglehart. Early experiments with prosptective payment of hospitals in: The New England Joumal of Medicine, voll 314, no. 22, pp. 1460-1464; F.A. Sloan, The American experience with case-based payment for hospital care: the DRG experiment, paper voor conferentie ower Alternatieve Entgeltverfahren in der Krankenhauswersorgung. Stuttgart, 1987. Tenslotte mogen ook de jaarlijkse rapporten wan de Prospective Payment Assessment Commission ten behoeve van het Congres niet onvermeld blijwen. 
zien die thans in ziekenhuiskringen heerst over de lopende bedden-en functiereductie/reallocatie. Deze operaties hebben directe consequenties woor het ziekenhuisbudget. De koppeling tussen het plannings- en financieringscircuit impliceert tevens, dat het lot van de kostenbeheersing in de intramurale sector niet alleen afhangt van de budgettering, maar ook van de effectiviteit van de planningswetgeving. Daar staat dan weer tegenover dat het belang van de planning ook weer niet moet worden overschat. In de nieuwe opzet van de budgettering bepaalt de planning namelijk 'slechts' 35 procent van het macrobudget voor de ziekenhuizen. ${ }^{33}$

Een tweede ontwikkeling betreft het streven naar een rechtvaardige toedeling van de totale budgettaire ruimte. Aanvankelijk liet deze rechtvaardigheid veel te wensen over. Bij de invoering van de budgettering in 1983 werd namelijk op puur pragmatische gronden het ziekenhuisbudget voor 1982 als basis gekozen. Op dit basisbudget werden vervolgens enkele mutaties (waaronder bezuinigingen) aangebracht. Wie in het basisjaar dus toevallig zuinig had geleefd, werd daarvoor gestraft en omgekeerd. Dit is het bekende probleem van 'the good and the bad guys:. ${ }^{34}$ De invoering van de zogeheten functionele budgettering in 1988 moet aan deze onrechtvaardigheid een eind maken door namelijk het ziekenhuisbudget veel meer te koppelen aan de capaciteiten en functies die aan het betreffende ziekenhuis in het planningscircuit zijn toegekend ${ }^{35}$ Deze operatie gaat overigens overigens wel met grote reallocatie-effecten gepaard. Zo blijkt 17,8 procent van alle ziekenhuizen 8 procent of meer te moeten inleveren en 17,1 procent 8 procent of meer te ontvangen. ${ }^{36}$ Beide typen reallocatie-effecten zullen nog de nodige bestuurlijke problemen opleveren.

In de derde plaats valt de opmars van het lokale overleg en daarmee van de onderhandelingscomponent bij de budgetbepaling op. De budgetbepaling is bepaald geen kwestie van het simpel toepassen van wat rekenregels uit een budgetformule. Een belangrijk deel van het budget wordt bepaald in het lokale overleg tussen ziekenhuizen en verzekeraars over de productie. Deze ontwikkeling begon in 1985 toen een onderscheid werd gemaakt tussen de vaste en variabele kosten en de variabele kosten afhankelijk werden gesteld van de productie-afspraken. ${ }^{37}$ Deze lijn is inmiddels verder doorgetrokken. Onder het regime van de functionele budget-

33 Ontleend aan het rapport Functiegerichte budgettering algemene ziekenhuizen van het Centraal Orgaan Tarieven Gezondheidszorg (COTG). Utrecht, 1987. De term macrobudget verwijst naar het budget dat resteert nadat de budgetten voor de bijzondere en infrastructurele voorzieningen op de totale budgettaire ruimte in mindering zijn gebracht.

34 Van der Reijden (1987).

35 COTG (1987).

36 COTG (1987).

37 Dit is de zogeheten Bredero-systematiek. Zie Rapport Commissie Uitwerking Normerings-/Tariefstructuur (Commissie Bredero), Utrecht, 1985. 
tering bedraagt de budgettaire ruimte voor het lokale overleg tussen ziekenhuizen en verzekeraars over de productie 40 procent van de totale budgettaire ruimte. ${ }^{38}$

Aan deze opmars van het lokale overleg zitten werschillende kanten. Zij maakt het bijvoorbeeld mogelijk om te profiteren van de voordelen van een decentrale besluitvormingsstructuur. Daar staat als gevaar tegenover dat de medische productie weer wordt aangejaagd. De toekonst moet uitwijzen in hoeverre deze vrees gerechtvaardigd blijkt. Een belangrijk punt in dit verband betreft de ontwikkeling van de machtsverdeling tussen aanbieders en verzekeraars. Zullen de verzekeraars zich inderdaad als effectieve "countervailing power" jegens de ziekenhuizen ontwikkelen?

In de vierde plaats kan ook een ontwikkeling in de richting van een meer taakstellende budgettering worden gesignaleerd waarbij het zickenhuisbudget fungeert als de financiële vertaling van inhoudelijke afspraken. Bij de invoering van de budgettering in 1983 was dat beslist niet het geval. Er was alleen sprake van een expliciete financiêle taakstelling en hooguit van een implicicte inhoudelijke taakstelling die ongeveer op het volgende neerkwam: 'Doet $U$ maar ongeveer hetzelfde als vorig jaar, maar dan wel met een lager budget!"

Als eerste begin van een budgetteringsproces en met mame als noodremprocedure valt een dergelijke eenzijdig financièle taakstelling wellicht nog te billijken. Maar op langere termijn schiet zij tekort. De ontwikkeling in de richting van een meer inhoudelijke taakstelling met daarbij een centralle rol voor het lokale overleg tussen ziekenhuizen en verzekeraars is dan ook van groot belang. Zij betekent immers dat niet alleen meer eenzijdig naar de uitgavenkant wordt gekeken, maar ook naar de inhoudelijke besteding van de middelen in relatie tot de behoefte aan zorg. Juist op dit laatste punt liet de opzet van de budgettering tot dusver veel te wensen over. Het door de oorspronkelijke opzet van de budgettering uitgelokte kostengerichte denken werkt naar mijn smaak uiteindelijk namelijk even fnuikend als het door de productiefinanciering uitgelokte opbrengstgerichte denken. Het gaat toch immers niet alleen om kosten, maar ook om wat men ervoor terug krijgt!

De vijfde en laatste ontwikkeling waarop ik de aandacht vestig betreft de invloed van de budgettering op de relatie tussen het ziekenhuis en de eerste lijn. In dit verband is onder meer van belang dat bij de budgetbepaling in het kader van de functionele budgettering 25 procent wan de totale budgettaire ruimte voor de ziekenhuizen is gereserveerd voor de factor adherentic. Daarbij ligt het in de bedoeling in de toekomst niet alleen te kijken naar de klinische adherentie, maar ook naar de poliklinische adherentie. Deze opzet zal er mijns inziens toe leiden, dat de zickenhuizen - zeker in concurrentiesituaties zoals in de grote steden - alles in het werk zullen stellen meer invloed op de eerste lijn uit te oefenen teneinde aldus de in. stroom van patiënten te beheersen. Mijn inschatting is dat deze ontwikkeling ver-

38 Bedoeld is het genormeerde budget, dat wil zeggen de arnvaardbare kosten 1983 minus de meerkosten bijzondere voorzieningen en de infrastructurele kosten. 
der wordt versterkt door het feit dat de ziekenhuizen zich steeds meer in het defensief gedrongen zien en de eerste lijn als een nieuwe "markt" zullen aanboren om het draagvlak voor eigen bestaan op langere termijn veilig te stellen. De budgettering vormt in ieder geval een interessante invalshoek woor de bestudering van de ontwikkelingen in de relatie tussen de eerste en tweede lijn. 


\section{Budgettering en de besturing van de gezondheidszorg}

In deze tijden waarin de kranten vol staan van de witvoering van het rapport-Dekker ontkomt men er niet aan aandacht te schenken aan de rol van de budgettering in thet kader van de macro-besturing van de gezondheidszorg. De kernvraag lijkt mij daarbij: welke rol kan de budgettering - en daarmee doel ik dan in het bijzonder op de functionele budgettering - spelen in het toekomstige besturingssysteem van de gezondheidszorg? Past de budgettering alleen in een door overheidsplanning gedomineerd besturingssysteem? Of is de budgettering ook goed toepasbaar in aen meer marktgesturde gezondheidszorg?

Naar mijn mening moet die laatste vraag bevestigend worden beantwoord. In een zuivere marktsituatie sluiten de verzekeraars en de ziekenhuizen een contract waarin voor een contractperiode afspraken worden vastgelegd over een bepaalde zorgverlening tegen een bepaald budget. Maar ook in cen systeem van gereguleerde concurrentie zoals recentelijk beschreven in de Dekkerbrief II kan de budgettering een belangrijke rol blijven spelen. De opzet van de functionele budgettering biedt daartoe zelfs goede perspectieven. In dit verband breng ik in herinnering dat onder het regime van de functionele budgettering ongeveer 35 procent van de budgettaire ruimte voor de ziekenhuizen wordt bepaald door de erkenningen krachtens de Wet Ziekenhuisvoorzieningen en ongeveer 40 procent door de productie-afspraken tussen de verzekeraars en de instellingen. Met name die productie-afspraken zijn hierbij van groot belang. Zij vormen als het ware het speelveld waarop het concurrentiespel kan worden gespeeld. Het principiele verschil tussen de huidige en toekomstige situatie lijkt mij daarbij, dat de huidige opzet van de budgettering nog niet voorziet in prijsconcurrentie terwijl dat in de opzet van de gereguleerde concurrentie à la Dekker wel het geval zal zijn. Samenvattend, kan de huidige budgettering dus als een aardige 'oefening in Dekker' worden beschouwd. 


\section{Draagt budgettering bij tot kostenbeheersing?}

Budgettering heb ik voorgesteld als een beleidsinstrument ter bereiking van bepaalde doeleinden. Vanuit een beleidswetenschappelijk perspectief rijst daarmee de vraag naar de effectiviteit van budgettering als beleidsinstrument. De theorie is mooi, maar hoe werkt het nu in de praktijk? In hoeverre beantwoordt de budgettering aan de verwachtingen ten aanzien van de kostenbeheersing en de verruiming van de beleidsvrijheid van de ziekenhuizen? Kortheidshalve zal ik mij hier beperken tot de vraag naar de effectiviteit van de budgettering in het licht van de kostenbeheersing. Niet dat de verruiming van de beleidsvrijheid van de ziekenhuizen een onbelangrijke doelstelling zou zijn. Verre van dat. Maar het probleem is dat er nauwelijks empirische gegevens beschikbaar zijn om uitspraken te doen over de verruiming van de beleidsvrijheid van de ziekenhuizen als gevolg van de budgettering.

Bij het onderzoek naar de effectiviteit van de budgettering stuit men onvermijdelijk op grote methodologische problemen. Twee problemen springen er daarbij uit. Het eerste probleem staat in de literatuur bekend als het vraagstuk van de causale toerekenung. ${ }^{39}$ Hoe kan men er zeker van zijn dat bepaalde veranderingen in de kostenontwikkeling aan de budgettering mogen worden toegeschreven? Deze vraag is met name ingegeven door het feil dat de kostenontwikkeling door tal van factoren wordt beinwloed. Te denken valt hier aan factoren als de inflatie, de vraag naar medische zorg of de ontwikkeling van de medische technologie. Verder speelt ook de flexibiliteit van het aanbod een belangrijke rol. ${ }^{40}$

Het tweede probleem zou ik willen aanduiden als het probleem van de communicerende vaten. Indien een bepaalde beperking van de kosten in de ziekenhuizen als gevolg van de budgettering gepaard zou gaan met forse kostenstijgingen elders in het gezondheidszorgsysteem, dan lijkt het ons misleidend om de budgettering zonder meer als een effectief beleidsinstrument voor te stellen. ${ }^{41}$ Die kostenstijging elders zal in de berekening moeten worden betrokken.

39 Zie bijvoorbeeld A. Hoogerwerf, H.J. Blommestein en I. Th. A. Bressers (red), Handboek beleidsevaluatie, Alphen a an den Rijn, 1984; P.H. Rossi, H.E. Freeman en S.R. Wright, Evaluation: a systematic approach, Beverly Hills/Londen, 1979.

40 Zo hangt de overschakeling van klinische behandeling naar dagbehandeling af van de beschikbare capaciteit ten anzien van de dagbehandeling. Het plamningscircuit kan hier voor veel vertraging zorgen. Zie bijwoorbeeld Beske et al (1987), p. 54.

41 Dit probleem is onder meer an de orde gesteld door Y. Dror, Public policymaking reexamined ${ }_{n}$ Scranton, 1968. De kem van het probleem is, dat het effectiviteitsonderzoek te beperkt wordt opgezet waardoor allerlei relevante neveneffecten buiten beschouwing blijven. 
Tegen de achtergrond van deze twee problemen is het duidelijk dat er bij het onderzoek naar de effectiviteit van de budgettering diverse adders onder het gras zitten. Deze adders nopen tot gedetailleerd onderzoek dat tot dusver evenwel ontbreekt. Mijn conclusies kunnen dus slechts voorlopig en voorzichtig zijn.

Wat valt er nu te zeggen over de effectiviteit van de budgettering met het oog op de kostenbeheersing? Laat ik beginnen met cen analyse van de ontwikkeling wan de exploitatiekosten van de algemene ziekenhuizen sedert 1976. Deze ontwikkeling is in figuur 1 weergegeven. 42

FIGUUR 1. UTTGAVEN ALGEMENE ZIEKENHUTZEN

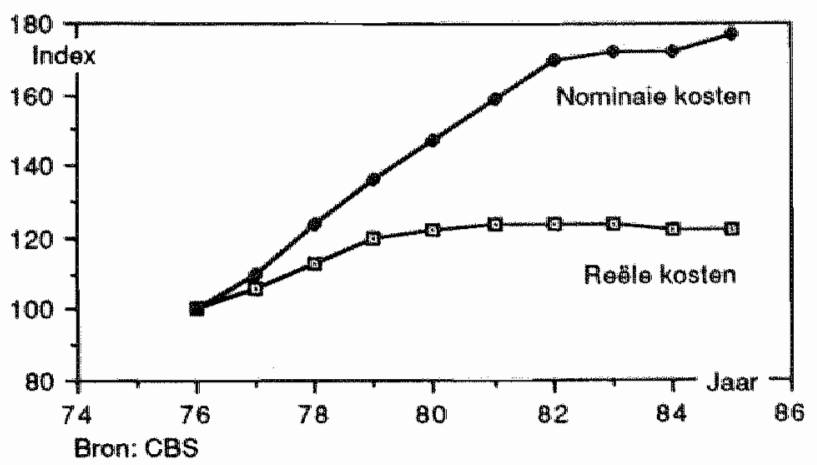

Figuur 1 maakt duidelijk dat de exploitatickosten van de ziekenhuizen in de periode 1976 - 1986 sterk zijn gestegen. Belangrijker is evenwel dat het stijgingspercentage drastisch blijkt terug te lopen en dat al ruim voor het jaar waarin de budgettering werd ingevoerd. De nominale kostenstijging is vanaf 1982 minimaal. De reelle kostenstijging blijkt vanaf 1983 zelfs negatief. Dat is voor het eerst na de Tweede Wereldoorlog. ${ }^{43}$

Figuur 1 zegt natuurlijk nog niets over de effectiviteit van de budgettering. Daartoe moeten de cijfers van de feitelijke kostenontwikkeling worden vergeleken nuet

$42 \mathrm{Bij}$ de berekening van de reẻle kostenontwikkeling is gebruik gemaakt van de prijsindexcijfers voor de gezinsconsumptie.

43 F.J. Hogewind en W. van der Windt, Kosten en dienstverlening in de intramurale gezondheidszorg 1980-1990: ower middelen, mensen en patiënten, NZIpublicatie, Utrecht, 1986. 
de in het FOGM aangegeven aanvaardbare kostenontwikkeling. ${ }^{44}$ Figuur 2 biedt dexe vergelijking. ${ }^{45}$

FIGUUR 2. EFFECTIVTTEIT VAN DE BUDGETTERING

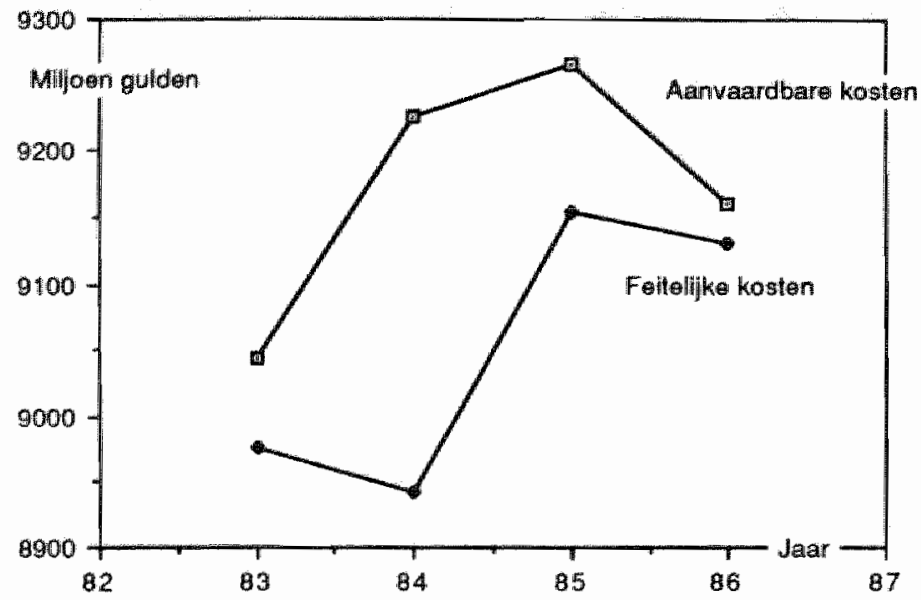

Bron: FOGM 1987 on 1988

Bij de interpretatic van figuur 2 dient woorzichtigheid te worden betracht. Dat heeft te maken met het probleem van de vergelijkbaarheid. De cijfers over de aanvaardbare kosten zijn namelijk afkomstig van het COTG en de cijfers over de feitelijke kosten van het CBS. Door deze verschillen in bron is enige ruis in de vergelijking helaas niet uit te sluiten.

Wat leert nu figuur 2? Om te beginnen suggereert een vergelijking van de aanvaardbare kosten met de feitelijke kosten, dat de budgettering vanuit het oogpunt van de kostenbeheersing als een effectief beleidsinstrument zou kunnen worden beschouwd. De feitelijke kosten blijven immers (ruimschoots) beneden de vastgestelde jaarlijkse plafonds.

44 Wij gan hicr kortheidshalve voorbij aan het onderscheid tussen de feitelijke kosten en de gefinancierde kosten.

45 In het FOGM wordt helaas geen splitsing gemaakt tussen de algemene en categorale ziekenhuizen. Vandaar dat de cijfers voor de aanvaardbare en feitelijke kostenontwikkkeling van de algemene en categorale ziekenhuizen tesamen worden genomen. 
Figuur 2 maakt tevens duidelijk, dat de budgettering met een beperkte reservevorming gepaard is gegaan. In de systematiek van de budgettering wordt het verschil tussen de aanvaardbare en feitelijke kosten immers gedefinieerd als de reserve aanvaardbare kosten die de instellingen zelf mogen behouden. Ik zou er echter met nadruk op willen wijzen, dat de cijfers over de reservevorming boterzacht zijn en dat er bijgevolg nauwelijks serieuze conclusies aan kunnen worden verbonden.

Hierbij spelen een aantal factoren mee. Om te beginnen laat de betrouwbaarheid van het cijfermateriaal te wensen over. Zo blijkt bijvoorbeeld uit enquêtegegevens van het COTG een negatieve reservevorming over 1986.46 Een lastig probleem is voorts, dat ziekenhuizen de kosten van bepaalde nog niet gerealiseerde voorzieningen onder de reserve aanvaardbare kosten kunnen hebben afgeboekt, bijvoorbeeld als gevolg van vertragingen bij de afgifte van vergunningen, erkenningen. leveringen, etcetera. Dit zou impliceren dat de feitelijke reservevorming in feite lager uitvalt. Daar staat weer tegenover dat een deel van de gecreęerde reserves reeds aan allerlei activiteiten kan zijn opgegaan met als logische consequentie dat de reserves in werkelijkheid veel groter zijn dan uit de figuur blijkt. Tenslotte kan de reservevorming ook nog duiden op een heel voorzichtige bedrijfsvoering van de ziekenhuizen waarbij eerst eens een poos de kat uit de boom wordt gekeken. Allerlei uitgaven worden daarbij naar een later tijdstip verschoven met als mogelijk gevolg dat de schijnbare rijkdom van vandaag omslaat in de armoe van morgen.

Het spreekt voor zich dat de analyse tot dusver op een hoog aggregatieniveau plaats heeft. Zij laat bijvoorbeeld geen conclusies toe op het niveau van de afzonderlijke ziekenhuizen. Dit is evenwel een belangrijk punt, met name tegen de achtergrond van het eerder genoemde probleem van de 'good guys and bad guys'. Ik volsta hier met de vermelding van een saillant resultaat uit een enquête van het COTG. ${ }^{47}$ Uit deze enquête blijkt namelijk een slijging van het aantal ziekenhuizen met een negatief exploitatieresultaat van 8 in 1984 naar 54 in 1985. Deze ziekenhuizen zullen dus in de reserves moeten tasten (mits uiteraard aanwezig). In hoeverre deze cijfers erop wijzen dat de instellingen steeds meer moeilijkheden van de budgettering ondervinden, valt zonder nader onderzoek moeilijk te zeggen. De omvang van deze moeilijkheden hangt onder meer af van het volume aan reserves en natuurlijk van de hoogte van het exploitatietekort. Daarnaast kunnen de tekorten ook duiden op falend management. Tenslotte wordt uit het onderzoek van het COTG ook niet duidelijk, in hoeverre de categorie van in financiele moeilijkheden geraakte ziekenhuizen samenvalt met de categorie van de 'good guys'.

Uit mijn analyse tot dusver komt naar voren, dat de budgettering op een hoog aggregatieniveau als een effectief beleidsinstrument moet worden beschouwd. Het budgetplafond wordt immers niet doorbroken. Het laat zich dan ook raden, dat de 
owerheid er als de kippen bij was on de budgettering tot een beleidssucces te verklaren. De wraag is evenwel of dit niet een wat kontzichtige benadering is. Daarbij denk ik niet alleen aan de eerder genoemde problemen van de causale toerekening en de communicerende vaten. Mij lijkt mij ook een groot bezwaar dat de doelstelling van de budgettering ten aanzien van de kostenbeheersing te veel als gegeven word aanvaard en daarmee ook automatisch te veel voor lief wordt genomen, een probleem dat zich overigens bij veel evalnatie-onderzoek voordoet.

Zo moet men zich goed realiseren, dat figuur 2 niets zegt over de haalbare besparingen. In feite stuit men hier op de wijze van vaststelling van de jaarlijkse plafonds voor de aanwaardbare kosten op macro-niveau. De vraag rijst of de financiele taakstelling in het FOGM niet vooral het karakter draagt van cen geextrapoleerde kostenontwikkeling waarop vervolgens een bepaalde korting (bezuiniging) is aangebracht. Veronderstelt men dat de intramurale gozondheidszorg door een grote mate van ondoelmatigheid wordt gekenmerkt, dan lijkt het succes van de budgettering al grotendeels bij voorbaat verzekerd. Zeker in de beginperiode zal dit het geval zijn.

Voorts blijft de besteding van de beschikbare middelen door de ziekenhuizen buiten beschouwing. Dat een ziekehuis onder het budgetplafond blifft is mooi meegenomen, maar slechts eén kant van de medaille, De andere kant van die medaille betreft de besteding van dat bedrag. De vergelijking wan het feitelijke met het aanvaardbare kostenniveau weerpiegelt het eerder besproken manco van de budgettering tot dusver, namelijk dat zij alleen een financiële taakstelling voor de ziekenhuizen impliceert maar geen inhoudelijke taakstelling. Om de budgettering tot beleidssucces te verklaren is dus meer noodzakelijk. 


\section{Effecten op de zorgverlening}

Een analyse van de effecten van de budgettering mag niet beperkt blijven tot de kostenbeheersing. Dat zou een te eng perspectief betekenen. De kwaliteit van de gezondheidszorg wordt immers uiteindelijk bepaald door de kwaliteit van de zorg en niet door het kostenniveau. Er dient met andere woorden ook aandacht te worden besteed aan de effecten van de budgettering op de zorgverlening. Deze zorgeffecten vormen tevens een politiek en maatschappelijk gevoelig onderwerp. Lang niet iedereen is er even gerust op, dat schadelijke gevolgen voor de kwaliteit van de zorgverlening zullen uitblijven. Er is dus een spanningsveld denkbaar tussen zorg en beheer. ${ }^{48}$ Van der Eyden sprak in dit verband reeds over de budgettose als ziekenhuisziekte. ${ }^{49}$

Het onderzoek naar de effecten van de budgettering op de zorgverlening staat in Nederland op een laag pitje. In een land als de Verenigde Staten ligt dat heel anders. Daar komt een stroom van publicaties los met allerlei empirische analyses van de effecten van het Prospective Payment System op de zorgwerlening. Er is zelfs een Prospective Payment Assesment Commission ingesteld die het Congres jaarlijks moet rapporteren over de zorgverleningseffecten. 50 Daarnaast wordt de uitvoering van het Prospective Payment System ook nog permanent geèvalueerd door de Commission on Professional and Hospital Activities (CPHA).

Bij het empirisch onderzoek naar de zorgverleningseffecten stuit men wederom op methodologische problemen. Ten eerste is daar weer het probleem van de causale toerekening. Ten tweede is de budgettering nog maar een betrekkelijk korte periode van kracht. Men mag dus niet uitsluiten, dat de effecten op de zorgverlening nog onvoldoende zijn uitgekristalliseerd.

Ten aanzien van de budgettering wordt verondersteld, dat zij op korte termijn leidt tot een vermindering van de zorgverlening in termen van zaken als vermindering van het aantal opnames en verrichtingen, verkorting van het aantal verpleegdagen en de gemiddelde ligduur, een verschuiving van klinische naar poliklinische zorg, etcetera. Een tweede veronderstelling is dat deze effecten de kwaliteit van de zorg niet aantasten en misschien zelfs verbeteren inzoverre zij een vermindering van overbodige zorg impliceren.

48 J. Schaaf en L. van der Veen, Het spanningsbeld tussen zorg en beheer, in: Stafleu, Leiding en organisatie in de gezondheidszorg. 1984/3, Alphen aan den Rijn.

49 A.P.J. van der Eyden, Budgettose, De ziekenhuisziekte, in: Medisch Contact, 225-1987, pp. 661-662.

50 Prospective Payment Assessment Commission, Medicare Prospective Payment System and the American Health Care System: Report to the Congres, Washington 1987. Dergelijke rapporten worden jaarlijks uitgebracht. 
Ik wal thans enkele effecten op de zorgverlening bespreken, te beginnen met het effect vart de budgettering op het volume aan verpleegkundig en paramedisch/medisch hulppersoneel. De hypothese luidt dat de budgettering dit volume zal drukken. In figuur 3 is de ontwikkeling in het volume aan verpleegkundig en paramedisch/medisch hulppersoneel in de vorm van indexcijfers weergegeven. De figuur suggereert dat de invoering van de budgettering heeft bijgedragen tot een vermindering van het volume aan verpleegkundig personeel. ${ }^{51}$ Voor wat betreft het paramedisch/medisch hulppersoneel lijkt de groei er na de invoering van de budgettering wit te zijn.

FIGUUR 3. VOLUME VERPLEEGKUNDIG EN PARAMEDISCH PERSONEEL
FIGUUR 4.

\section{VOLUME VERPLEEGDAGEN}

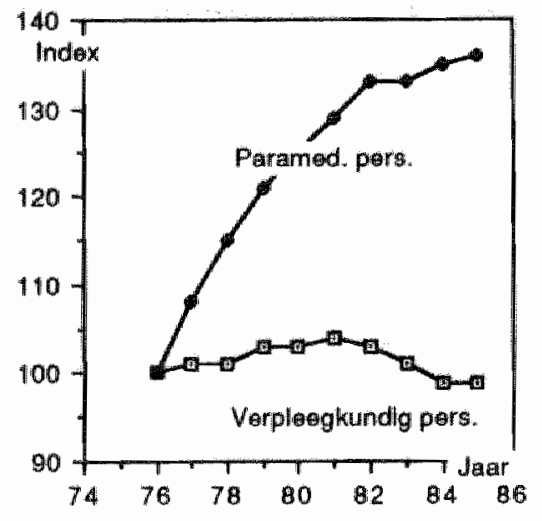

Bron: NZI

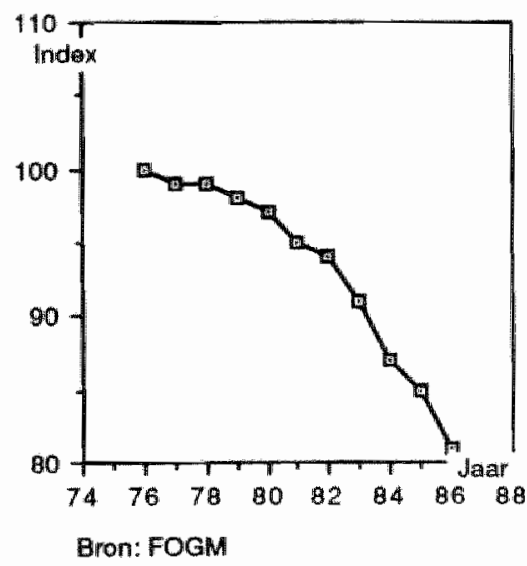

Een volgend effect betreft het aantal verpleegdagen. De hypothese luidt hier dat de budgettering zal leiden tot een vermindering van het aantal verpleegdagen. 52 Een dergelijke vermindering bewordert immers de kostenbesparing. Figuur 4 betreft de ontwikkeling van het volume aan verpleegdagen sedert 1986. Uit deze figuur kunnen twee conclusies worden getrokken. De eerste conclusie luidt dat de daling van het volume aan verpleegdagen al ruim voor de budgettering is ingezet. Maar

51 De Commissie-Deklker is van oordeel dat een deel wan de bezuinigingen in de gezondheidszorg is afgewenteld op de werpleegkundige zorg.

52 Er zijn ook andere verklaringen denkbaar. Zie F.A. Sloan en J. Valvona, Why has hospital length-of-stay declined? An evaluation of alternative theories, in: Social Science and Medicine, vol. 22, 1986, pp. 63-73. 
bij wijze van tweede conclusie lijkt het erop dat de budgettering bijdraagt tot een versnelde daling van het aantal verpleegdagen.

Een derde effect betreft de gemiddelde verpleegduur. De theorie voorspelt hier een (versnelde) daling van de verpleegduur. ${ }^{53}$ Figuur 5 geeft de ontwikkeling van de gemiddelde verpleegduur weer. Uit deze figuur blijkt van een versnelde daling van de gemiddelde verpleegduur in Nederland geen sprake. De gemiddelde verpleegduur loopt al gedurende een langere periode geleidelijk terug. Deze daling blijkt vrij goed gespreid over alle specialismen en diagnoses. ${ }^{54}$

FIGUUR 5.

GEMIDDELDE VERPLEEGDUUR

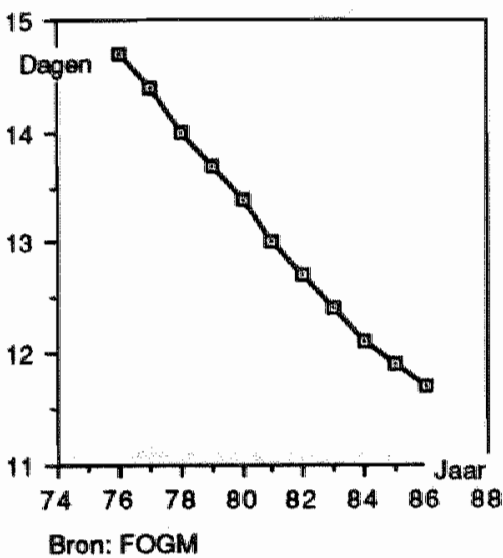

FIGUUR 6. AANTAL OPNAMEN (PER HOOFD VAN DE BEVOLKING)

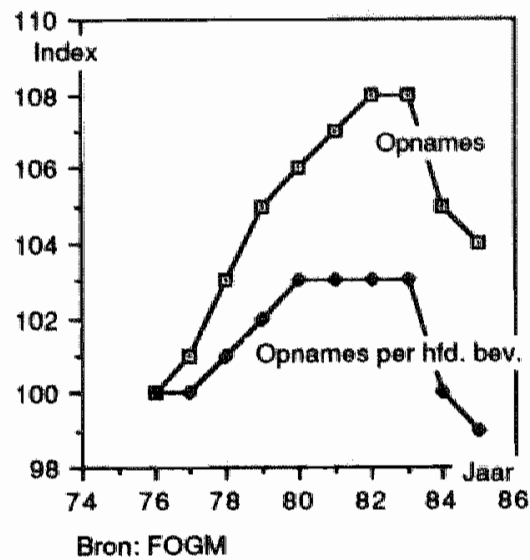

Een vierde effect betreft het aantal opnames. De theorie voorspelt hier een daling. Figuur 6 laat in dit verband aan duidelijkheid weinig te wensen over. Zowel het aantal opnames als het aantal opnames per hoofd van de bevolking dalen. Zeer opmerkelijk is hierbij dat deze daling in 1983 - het jaar van de invoering van de budgettering - is ingezet!

Een vijfde effect betreft de ontwikkeling van het polikliniekbezock. De verwachting is hier dat de invoering van de budgettering tot een versnelde groei wan het polikliniekbezoek zal leiden. In figuur 7 is de groei van het polikliniekbezoek

53 Aan deze daling komt naturrlijk een einde. Dit is het zogeheten 'ceiling effect'.

54 Zie Hogewind en Van der Windt (1986). 
sedert 1976 weergegeven. Uit deze figur kan worden opgenaakt, dat tegen de verwachting in geen sprake is van een versnelde toename van het polikliniekbezoek. Er blijkt weeleer sprake van een geleidelijke toename. De budgettering heeft hier geen trendbreuk veroorzaakt.

\section{FIGUUR 7. VOLUME POLIKLINIEKBEZOEKEN}

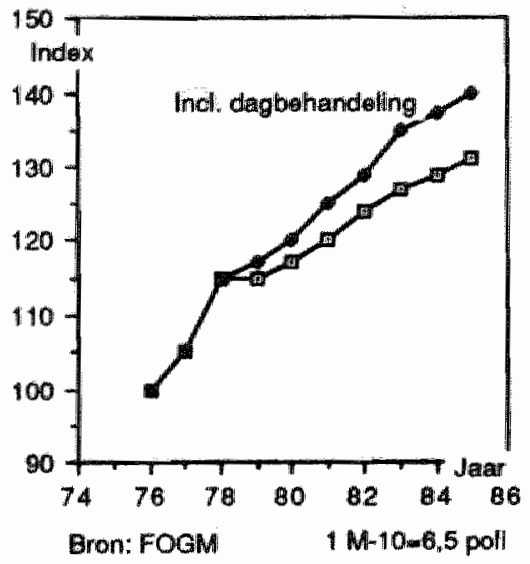

Tenslotte wil ik nog ingaan op de effecten van de budgettering voor de zorgintensiteit, gemeten aan de hand van het aantal verrichtingen per opname. Hierbij moet onderscheid worden gemaakt tussen de productie per opname (klinische productie) en de productie per polikliniekbezoek (poliklinische productie).

Bezien wij om te beginnen de ontwikkeling van de klinische productie. In figuur 8 zijn een aantal ontwikkelingen weergegeven. Deze ontwikkelingen betreffen het functio-, Jaboratorium en het rôntgenonderzoek per 100 opnames alsmede het aantal operaties per 100 opnames. Het beeld is gevarieerd, maar aan de cijfers zou niettemin toch de voorzichtige conclusie kunnen worden verbonden dat de groei er sedert de invoering van de budgettering uit is. Dit geldt in leder geval voor het laboratoriumonderzock en de operaties. 
FIGUUR 8.

KLINISCHE PRODUCIIE PER OPNAME
FIGUUR 9.

PRODUCTIE PER POLIKLINIEKBDZOEK

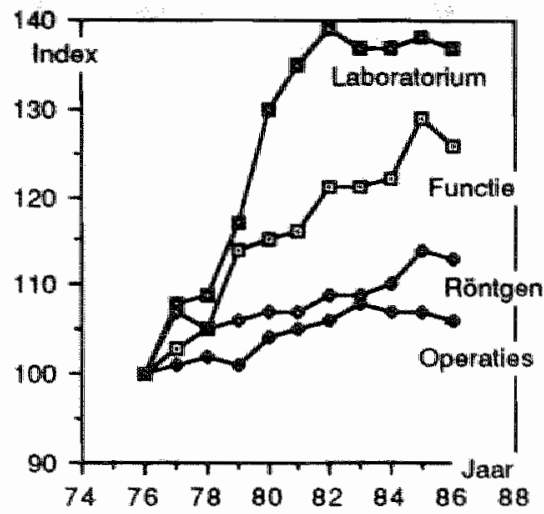

Bron: NZU-Productis Statistiek

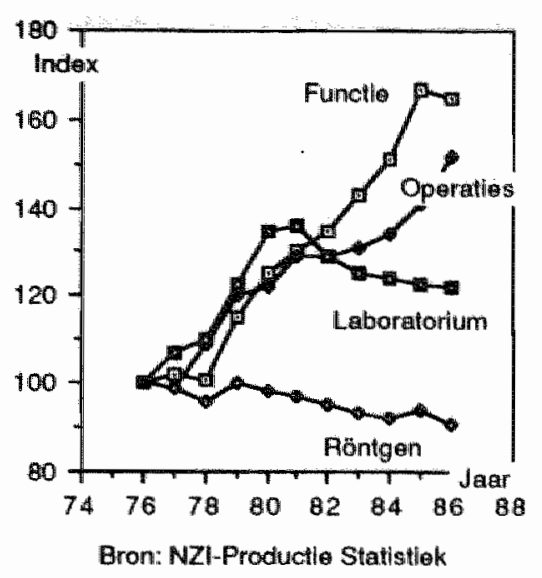

In figuur 9 is voor dezelfde categorieën van verrichtingen de poliklinische productie weergegeven. Hier ligt het beeld onduidelijker dan bij de klinische productie. Voor wat het laboratoriumbezoek lijkt er sprake van een stabilisatie die overigens al ruim voor 1983 is ingezet. Ook het röntgenonderzoek beweegt zich in dalende lijn. Daar staat evenwel tegenover dat de poliklinische productie ten aanzien van het functie-onderzoek en de operaties blijft stijgen. Mogelijkerwijs dat dit samenhangt met de ontwikkelingen in de klinische productie dienaangaande.

Tot zover de weergave van enkele onderzoeksresultaten. Als algemene conclusie kan worden geformuleerd, dat de invoering van de budgettering ten aanzien van het volume aan verpleegkundig/paramedisch en medisch hulppersoneel, het aantal verpleegdagen en het aantal opnames het verwachte effect te zien geeft. Voor wat betreft de gemiddelde verpleegdurr is dat niet het geval. De stijging van het polikliniekbezoek is niet versneld. Ten aanzien van de klinische en poliklinische zorgintensiteit is er sprake van cen gevarieerd beeld.

De hier gepresenteerde analyse van de zorgeffecten draagt vanzelfsprekend een voorlopig karakter. Voor een beter inzicht is veel aanvullend onderzoek noodzakelijk. Een belangrijke stap daarbij betreft een drastische verlaging van het aggregatieniveau. Analyses op hoog aggregatieniveau hebben immers als nadeel dat eventuele belangrijke tendensen op lagere niveaus niet aan het licht worden gebracht (verlies aan informatie). Nadere detaillering van het onderzoek is dan ook noodzakelijk (bijwoorbeeld per categorie van diagnostische/therapeutische verrichtin- 
gen). Verder zijn ook tall wan andere interessante parameters tenkbaar zoals bijvoorbeeld de invloed van de budgettering op het gebruik en de diffusie van medische technologie, op de ontwikkeling van de verhouding arbeid - kapitaal bij de zorgverlening of op de ontwikkeling van de nazorg en thuiszorg. Voor wat dit laatste betreft blijkt uit Amerikaanse onderzoekingen naar de effecten van de invoering yan het Prospective Payment System, dat dit nieuwe bekostigingssysteem allerlei veranderingen op gang brengt in het totale product van de gezondheids20rg. 55

De onderzoeksresultaten geven uiteraard geen antwoord op de hamvraag of de invoering van de budgettering ook een bepaalde kwaliteitswinst of cen bepaald kwaliteitswerlies in de zorgverlening heeft teweeg gebracht. Bij de kwaliteitswinst kan dan bijvoorbeeld worden gedlacht aan de vermindering van allerlei onnodig onderzock. Onderzoek naar gevolgen van de budgettering voor de kwaliteil van de zorgverlening wormt naar mijn mening een belangrijk thema van onderzoek. Een groot probleem is daarbij overigens hoe operationele inhoud te geven aan zulke moeilijke begrippen als $\mathrm{k}$ waliteitswinst of kwaliteitsverlies.

55 M.J. Long et al, The effects of PPS on hospital product and productivity, in: Medical Care, vol. 25, June 1987, pp. 528-538; zie voorts M.A. Morrisey et al, Medicare Prospective Payment and post-hospital transfers to subacute care (unpublished ins, 1987). 


\section{Effecten op beleidsvoering en organisatie van ziekenhuizen}

Ter afsluiting van mijn betoog wil ik aandacht schenken aan de gevolgen van de budgettering op de beleidsvoering en organisatie van de ziekenhuizen. Vanuit de optiek van de overheid is dit een belangrijk thema. Het welslagen van de budgettering hangt immers sterk af van de wijze waarop de ziekenhuizen er in de praktijk mee omgaan. Maar ook vanuit de optiek van de ziekenhuizen gaat het om een interessant onderzoeksthema. De budgettering kan immers als een belangrijke verandering in de omgeving van de ziekenhuizen worden beschouwd.

De budgettering verhoogt de externe druk op de ziekenhuizen. De omgeving van deze instellingen lijkt van rustig in turbulent vaarwater gekomen. Uiteraard spelen daarbij ook talrijke andere factoren mee zoals bijvoorbeeld de planningswetgeving (bedden-en functiereductie), de aanhoudende conflicten over de honorering van de medisch specialisten en niet te vergeten de voortslepende discussie over de herstructurering van de gezondheidszorg.

Op grond van organisatietheoretische inzichten kan worden verondersteld, dat de budgettering implicaties heeft voor het interne functioneren van de ziekenhuizen. Deze aan de contingentietheorie ontleende veronderstelling blijkt de discussie inderdaad te domineren. Vat men deze discussie kort samen, dan springen er naar mijn mening drie punten uit.

Ten eerste valt op dat de discussie vooral een normatieve toonzetting kent. Steeds weer wordi gewezen op de noodzaak van de ontwikkeling van strategisch beleid of ook wel strategisch management. ${ }^{56}$ In de internationale literatuur spreekt men in dit verband over de overgang van "hospital administration to hospital management. ${ }^{57}$ In nauwe samenhang hiermee worden allerlei voorstellen gelanceerd voor veranderingen in de interne organisatiestructuur van de ziekenhuizen, want aldus McMahon c.s.: 'Without adapting the hospital's organizational structure to the shift in fiscal orientation (bedoeld is de inwoering van het Prospective Payment System), the institution may fail'. 58 Daarbij gooien matrixachtige constructies meestal hoge ogen, hetgeen natuurlijk nauwelijks verwondering wekt tegen de achtergrond van de complexe structuur van ziekenhuizen met zijn heterogene productiepakket en de alom aanwezige noodzaak tot multidisciplinaire samenwerking.

56 J.B.M. Edelman Bos, Strategisch management in de gezondheidszorg: mission impossible?, Rotterdam, 1987.

57 Beske et al (1987); J.R. Griffith, The well-managed community hospital "Ann Arbor, 1987.

58 L.F. McMahon, R.B. Fetter, J.L. Freeman en I.D. Thompson, Hospital matrix management and DRG-based prospective payment, in: Hospital \& Health Services Administration, januari/februari 1986, pp. 62-74. 
De inwoering van de budgettering vergt dus veranderingen in het interne funetioneren van ziekenhuizen. De vraag is nu in hoeverre deze veranderingen optreden. Deze wragg brengt mij bij een tweede opvallend punt, namelijk dat hierover weinig. bekend is. Gedegen empirisch onderzoek naar de beleidsvoerings- en organisatieeffecten van de budgettering ontbreekt tot dusver vrijwel geheel. ${ }^{59}$ De kennis over deze effecten komt niet boven het niveau uit van een werzameling van overigens soms waardevolle impressies.

Uit deze impressies kornt naar voren - en dat is mijn derde punt - dat de budgettering inderdaad als cen belangrijke stimulans tot beleids- en organisatieverandering werkt. Er lijken allerlei veranderingen in gang gezet en sommige waarnemers beoordelen deze veranderingen zelfs als het belangrijkste effect van de budgettering. Tegelijkertijd bestaat echter ook de indruk dat het veranderingsproces traag verloopt. Er zijn zelfs aanwijzingen dat het veranderingsproces stagneert. 60

Ik wil nu op een drietal aspecten van dit veranderingsproces dieper ingaan. Deze aspecten zijn achtercenvolgens het aspect van de doelgerichtheid, het aspect van de informaticvoorziening en het tenslotte het aspect van de integratie. ${ }^{61}$

Beginnen wij met het aspect van de doelgerichtheid. Dit aspect betreft de mate waarin sprake is van cen expliciet ziekenhuisbeleid, dat wil zeggen een beleid met duidelijke doeleinden en prioriteiten en met een redelijk uitgewerkt instrumentarium om deze doeleinden te bereiken. Het ziekenhuisbeleid maakte tot voor enkele jaren een weinig ontwikkelde indruk. Nu was dat vanwege de afwezigheid van budgettaire schaarste ook niet zo'n probleem. Een hogere productie leverde automatisch meer inkomsten op. De directie hoefde zich evenmin veel zorgen te maken over de productie, want dat was vooral een zaak van de dokters. Ook ten aanzien van een uitbreiding wan het aantal functies dat een ziekenhuis uitoefende of aen uitbreiding wan de medische staf bestonden geen echte financiële drempels. Elke uilbreiding genereerde haar eigen inkomstenstroom. ${ }^{62}$

Het is duidelijk dat het toncel inmiddels aanzienlijk is veranderd. Een passier beleid voldoet niet langer. Ziekenhuizen moeten een doelgericht beleid voeren. Daarin zal onder meer aandacht moeten worden besteed aan het gewenste functiepakket en aan

59 Een witzondering vormt het rapport "De resultaten van een experiment met budgettering in vier algemene ziekenhuizen; uitgebrach door het Nationaal Zickenhuisinstituut, Utrecht, 1986.

60 J. Schauf, Modellen en ervaringen in Nederland, lezing op LSV-studiedag over "Medisch specialist: intermediair tussen patient en budget", 17-11-1987.

61. ZieA. Hoogerwerf (red), Succes en falen wan overheidsbeleid, Alphen an den Rijin, 1983.

62 Zie bijvoorbeld F.J.M. Werner, Inleiding Congres Cezondheid en Financien. 
de relatie van het ziekenhuis ten opzichte van de eerstelijns zorg. ${ }^{63}$ Vanwege het budgettaire plafond zijn expliciete keuzes onvermijdlelijk ${ }^{64}$ Deze en andere zaken zullen aan belang winnen bij het lokaal overleg tussen ziekenhuizen en verzekeraars. Ten behoeve van dit overleg moeten ook beleidsplannen worden opgesteld.

Komt zo'n doelgericht ziekenhuisbeleid nu ook van de grond? Uit het optuigen van allerlei interne commissies ter voorbereilding van ziekenhuisplannen, medische, verpleegkundige en andere soorten beleidsplannen kan worden opgemaakt, dat er zeker sprake is van een ontwikkeling in de richting van een expliciet ziekenhuisbeleid. ${ }^{65}$ Tegelijk bestaat de indruk dat er nog een lange weg te gaan is. Beleidsplannen dragen waak vooral het stempel van een opsomming van verlangens. Van een duidelijke prioriteitsstelling en van een koppeling van de planworming aan budgettaire kaders is nog weinig sprake. ${ }^{66}$

De interne budgettering, dat wil zeggen de allocatie van het beschikbare budget over de eenheden van het ziekenhuis, vormt eveneens een belangrijk onderdeel van het ziekenhuisbeleid. In dit verband wordt wel onderscheiden tussen twee modellen, te weten het beheers- en het beleidsmodel. ${ }^{67}$ Het beheersmodel wordt gekenmerkt door een sterk incrementalistische begrotingsprocedure. Iedere eenheid krijgt iets meer of minder dan het jaar daarvoor. De besteding van dat budget is een probleem van een lagere orde. De impliciete veronderstelling is dat de betreffende eenheid 'minder van hetzelfde' zal produceren. In het beleidsmodel fungeert het budget van de eenheden daarentegen als de financiële vertaling van cen beleidsplan. Directie en eenheden onderhandelen niet alleen over een budget, maar spreken ook een inhoudelijke taakstelling af. ${ }^{68}$ Het beleidsmodel wordt dus gekenmerkt door cen meer rationele begrotingsprocedure die doet denken aan zero-base budgeting.

In hoeverre vindt het beleidsmodel in de praktijk toepassing? Ik zou hier de hypothese willen wagen, dat de initiele reactie op de invoering van de budgettering vooral in het teken van het beheersmodel heeft gestaan. Ter toelichting op deze hypothese wijs ik erop, dat de budgettering voor de ziekenhuizen een totaal nieuwe situatie betekende. Men werd geconfronteerd met een budgettaire limiet en in sommige gevallen reeds van meet af aan met budgettaire schaarste. Er leefde on-

63 Men denke in dit verband nogmaals aan de opzet van de functionele budgettering.

64 Zie bijvoorbeeld $H_{\text {uI }}$. Wickings, Experiments with clinical budgeting in the British NHS, in: G. Schrijwers (red), Ziekenhuis en budget: Nederland, Amerika, Engeland en Zweden, Lochem, 1982.

65 NZI-evaluatierapport (1986); H.van Vondel (red), Ervaringen met en perspectief van interne budgettering, Lochem, 1986.

66 Zie het evaluatierapport van het Nationaal Ziekenhuisinstituut.

67 M.G. Boekholdt en J.A. Machielsen, Budgetteren in ziekenhuizen: cen complex probleem, in: Het Ziekenhuis, 1983, nrs. 6,7 en 8.

69

Zie Wickings (1982). 
zekerheid of men wel met het budget zou witkomen. Voorzichtigheid werd dus moeder van de porseleinkast. Daar kwam nog bij dat er veel onzekerheid bestond over de exacte hoogte van het budget.

Naast de doelgerichtheid wormt de informatiewoorziening een tweede belangrijk aspect van het organisatieveranderingsproces dat door de budgettering in gang is gezet. Ook hier overheerst de normatieve toonzeting. Steeds opnieuw wordt gewezen op het belang van een goede informatievoorziening. Een expliciet ziekenhuisbeleid en een effectieve kostenbeheersing als onderdeel daarvan vragen om tijdige en adequate informatie. De bestaande informatiesystemen bieden veelal anvoldoende mogelijkheden tot een goede besluitvormingsondersteuning.

Onder het oude regime van het vergoedingenstelsel was de informatiebehoefte minder groot. Globale informatie over de interne kostenstructuur en het verloop van de productie bleek voldoende. Deze informatie droeg vooral een registrerend karakter. ${ }^{69}$ De invoering van de budgettering vergt evenwel niet zozeer registrerende als wel sturende informatie die de directie bijvoorbeeld meer inzicht verschaft in de kosten en opbrengsten per kostenplaats en in de kostendragers van de organisatic. Het informatiesysteem dient ook meer inzicht te verschaffen in de kosten van medische besluitworming. Dergelijke informatie is een belangrijke voorwaarde voor inhoudelijke discussies tussen professie en directie over de besteding van schaarse middelen.

Analyses van bestaande ziekenhuisinformatiesystemen wijzen uit, dat deze systemen zowell conceptueell als technisch gedateerd zijn. ${ }^{70}$ Daar komt bij dat de markt voor deze systemen slecht blijkt te werken en de vereiste innovatie tegenhoudt. Voorts mag niet uit het oog worden verloren, dat de ziekenhuizen in het verleden reeds grote investeringen in informatiesystemen hebben gedaan. Het is de vraag of er voldoende bereidheid bestaat hierin opnieuw grote bedragen te investeren.

Overigens lopen er thans wel diverse projecten die juist tot doel hebben om vooruitgang te boeken op het terrein van de besluitvormingsondersteunende systemen. Voor wat de Rijksuniversiteit Limburg valt hierbij bijvoorbeeld te denken aan het DRG-project en aan het opstarten van het Interuniversicair Instituut voor Medical Technology Assessment.

69 L.M.J. Groot, Incentives for cost-effective behavior: a Dutcly experience, paper voor Third Symposium on Health and Economics, Antwerpen, 1985.

70 Zie ZIS Release 2000, opgesteld door F.M.M. yan Iersel (James Martin Associates), W. Ouwerkerk (O\&K Advies) en J. Op Hey (James Martin Associates) in opdracht van WVC; voorts E.A. Mantz, E. van der Groep en J. van Lieshout, Informatiebeleid en informatieplanning, Evaluatie wan een praktijkonderzoek bij 281 organisaties, in: Informatie, 1987, pp. 649-760. 
Resteert tenslotte het aspect van de integratie tussen de medische besluitworming enerzijds en de financieel-ecomische en overige besluitvorming anderzijds. Onder het regime van de outputfinanciering vormde deze integratie nauwelijks een probleem. Dat was ook niet zo verwonderlijk, want de belangen van medische staf en directie (bestuur) liepen in principe parallel. Maximalisatie van de productie en groei van de instellingen waren woor beide partijen gunstig. Er golden weinig beperkingen want elke investering verdiende zichzelf terug. 71 Maar de integratie droeg tegelijk ook een sterk eenzijdig karakter. Zij stond namelijk in het teken van een eenrichtingsverkeer met daarbij een dominerende positie voor de medische besluitvorming. Deze eenzijdige integratie vindt men aardig werwoord in een studie van Mur-Veeman naar het ziekenhuisbeleid. Zij noteert daarin de volgende uitspraak van een directielid: 'Alles wat de medische staf doet, is voor ons belangrijk en er mot heel wat gebeuren, willen directie en besturr niet ingaan op de initiatieven van de sta?. ${ }^{72}$

Deze vorm van eenzijdige integratie is typerend voor wat Mintzberg heeft aangeduid als een professionele bureaucratie. ${ }^{33}$ Het algemeen ziekenhuis is een dergelijke bureaucratie. Een dergelijke organisatievorm wordt gekenmerkt door een grote mate van autonomie van de professionals in het productieproces en in het verlengde hiervan, een betrekkelijk zwakke positie van de directie. De professionals, in casu de medisch specialisten, hebben het de facto voor het zeggen. De ziekenhuisorganisatie staat dus ver van een hiërarchie. ${ }^{74}$

In een situatie van budgettering voldoet deze eenzijdige integratie niet langer. Deze budgettering berust immers op de veronderstelling dat de directie in staat is aard en omvang van de activiteiten zodanig te sturen, dat de kosten binnen vooraf gestelde kaders blijven. Dit impliceert een toenemende onderlinge afhankelijkheid tussen directie en medische staf. De integratie zal meer tweezijdig moeien worden. Of zoals Scott het zou zeggen: het ziekenhuis moet van een 'autonomous professional organization' uitgroeien tot een 'conjoint professional organization" waarin het accent juist ligt op een gemeenschappelijke verantwoordelijkheid. ${ }^{75}$

In veel beschouwingen over de organisatorische effecten van de budgettering wordt steeds weer benadrukt, dat een noodzakelijke voorwaarde voor het welslagen van de budgettering is gelegen in het feit dat de medisch specialisten aan de besluit

71 Vergelijk A.S. Detsky, The economic foundations of national health policy, Cambridge (Mass), 1978.

72 Mur-Veeman (1982).

73 H. Mintzberg, The structuring of organizations, Englewood Cliffs, 1979.

74 D.W. Young en R.B. Saltman, Prospective reimbursement and the hospital power equilibrium: a matrix based management control system, in: Inquiry. 20, Spring 1983, pp. 20-33.

75 W.R. Scott, Making professional work: three models of control for health organizations, in: Health Services Research, 1982. 
vorming over hel ziekenhuisbeleid en de interne budgettering participeren. Dat geldt heel in het bijzonder voor de zogeheten poortspecialisten, want zil oefenen grote invloed uit op het activiteitenniveau. Zonder hun actieve betrokkenheid is de budgettering op instellingsniveat gedoend to mislukken.

Hoc staat het nu in de praktijk met deze nieuwe vorm van integratie? Om te beginnen zou ik willen benadrukken, dat de budgettering in het kamp van de specialisten met weinig enthousiasme is ontvangen. Dat viel natuurlijk ook niet te verwachten, want zij betekent üteindelijk minder geld en knaagt bovendien aan de gevestigde positue van de medische staf in het ziekenhuis. Het onder het ziekenhuisbudget brengen van de specialisten - zoals voorgesteld door de CommissieDekker - wordt met kracht van de hand gewezen. Verder mag men niet vergeten, dat het integratieproces zich niet afspeelt in een bestuurlijk vacuüm, maar in een context van bezuinigingen, bedden-en functiereducties, een strijd over de honoraria en meer in het algemeen cen toenemend wantrouwen tegen het overheidsbeleid.

Dat het integratieproces moeizaam verloopt of misschien zelfs stagneert is dus niet verwondcrlijk. Maar dit alles laat onverlet, dat het veranderingsproces doorgat. In dit verband wil ik wijzen op het van de grond komen van nieuwe begrotingsprocedures met daarin ruimte voor actieve participatie van de medische staf, op de rol van de medische staf bij het opstellen van medische en andere beleidsplannen, etcetera. Voorts mag het recente rapport van de Landelijke Specialisten Vereniging (LSV) 'De special ist van morgen' niet onvermeld blijven. Hierin wordt onder meer gepleit op het belang van een managementorièntatie bij specialisten. Een andere interessante gedachte betreft het pleidooi voor de opsplitsing van het ziekenhuis in kleinere organisatorische eenheden per specialisme of enkele specialismen tesamen. Kernpunt van deze opzet is dat aan de eenheid een deelbudget wordt toegekend op grond van het medisch beleidsplan', zo kan men in de LSV-nota lezen. ${ }^{76}$ Hier wordl dus een onverbloemd pleidooi voor contractmanagement of ook wel 'clinical budgeting ${ }^{77}$ gehouden, cen besturingsconstructie met uiteraard vele haken en ogen en wellicht nog niet geheel doordachte consequenties. Maar toch. Wie zoiets pak weg 10 jaar geleden zou hebben voorgesteld, zou waarschijnlijk niet helemaal serieus zijn genomen.

76 Landelijke Specialisten Vereniging. De specialist van morgen: e en toekomstvisie in antwoord op de problenatiek van vandaag, Utrecht 1988.

7 Zie hierover H.I. Wickings, Experiments with clinical budgeting in the British NHS. 


\section{Besluit}

Met deze beschouwing over enkele effecten van de budgettering op de beleidsvoering en organisatie van de ziekenhuizen kom ik aan hel einde van mijn betoog. Ik ben met $U$ in kort tijdsbestek een breed terrein langs gelopen. Om te beginnen kwamen een aantal aspecten van en trends in de budgettering van algemene ziekenhuizen aan de orde. Een algemene conclusie zou hier kunnen luiden, dat de budgettering niet meer valt weg te denken uit het huidige systeem van de gezondheidszorg. Vooral ook omdat zij goed inpasbaar lijkt in een meer marktgestuurde gezondheidszorg, is met de budgettering een weg ingeslagen die mij voorlopig onomkeerbaar lijkt. Voor de pure productiefinanciering geldt slechts een "Das war einmal'.

Voorts kwamen ook verschillende effecten van de budgettering ter sprake. Daarbij moest ik bij gebrek aan onderzoek op diverse plaatsen in mijn betoog speculeren en vragen open laten. Dat betekent in feite dat er nog een heel terrein voor empirisch onderzoek braak ligt. Het is dit terrein dat ik samen met de leden van mijn vakgroep en andere onderzoekers in onze zo volprezen interfacultaire wetenschapsorganisatie verder hoop te exploreren.

* Ik zeg in het bijzonder Dr. E. Elsinga. Dr. A.A. van Es, Prof. L.M.J. Groot en Dr. Drs. J.M.J.C. Scheres dank voor hun commentaar op een eerdere versie. 